\title{
CLAIMS AGAINST THIRD-PARTY RECIPIENTS OF TRUST PROPERTY
}

\author{
DAVID SALMONS*
}

\begin{abstract}
This article argues that claims to recover trust property from third parties arise in response to a trustee's duty to preserve identifiable property, and that unjust enrichment is incompatible with such claims. First, unjust enrichment can only assist with the recovery of abstract wealth and so it does not assist in the recovery of specific property. Second, it is difficult to identify a convincing justification for introducing unjust enrichment. Third, it will work to the detriment of innocent recipients. The article goes on to show how Re Diplock supports this analysis, by demonstrating that no duty of preservation had been breached and that a proprietary claim should not have been available in that case. The simple conclusion is that claims to recover specific property and claims for unjust enrichment should be seen as mutually exclusive.
\end{abstract}

KEYWORDS: trusts, third parties, proprietary claims, knowing receipt, restitution, unjust enrichment, Re Diplock.

\section{INTRODUCTION}

According to orthodox trust principles, where property is transferred in breach of trust, a beneficiary can either bring a proprietary claim to recover the property or a personal claim against a knowing recipient of the trust property (hereinafter, the combination of these two claims will be referred to as the "equitable regime"). However, it has been suggested in a number of recent authorities that beneficiaries should also be able to bring a strict liability personal claim for unjust enrichment against third-party recipients of trust property. ${ }^{1}$ The availability of a strict liability personal claim will be of central importance where an innocent recipient has dissipated trust property but where they are still enriched. This issue also has further implications

\footnotetext{
* I would like to thank Dr Astrid Sanders for reading numerous versions of this article, as well as the two anonymous reviewers. Address for Correspondence: Aston Law, Aston Business School, University of Aston, Birmingham, B4 7ET, UK. Email: d.salmons@aston.ac.uk.

${ }^{1}$ Relfo v Varsani [2014] EWCA Civ 360, at [1], per Arden L.J.; Barclays Bank Plc v Kalamohan [2010] EWHC 1383, at [74], per Proudman J.; AAH Pharmaceuticals Ltd. $v$ Birdi [2011] EWHC 1625 (QB), at [29], [38], per Coulson J.; MGN Ltd. v Teresa Horton [2009] EWHC 1680 (QB); [2009] All E.R. 99 (Eng), at [4], [36], per Tugendhat J.; Zumax Nigeria Ltd. v First City Monument Bank Plc [2016] EWCA Civ 567, at [78]-[80], per Kitchin L.J.
} 
such as determining who should bear the burden of proving the recipient's fault and also the possible introduction of the change of position defence where the recipient retains traceable proceeds of trust property.

The position in this article is that strict liability personal claims are inappropriate where the beneficiary has a right to recover specific property. Existing accounts have sought to reject the introduction of unjust enrichment on the basis of the recipient's security of receipt or on the claimant's pre-existing equitable title. This article explains that neither of those explanations provide a clear enough reason for rejecting unjust enrichment. Instead, the original contribution of this article is the argument that the underlying principle of the equitable regime is to enable the recovery of property transferred in breach of the trustee's duty to preserve the beneficiary's interests in identifiable property (the "duty of preservation"). This is important for four reasons. First, a claim for unjust enrichment does not provide an appropriate response to the breach of the trustee's duty of preservation as it only enables the recovery of value as opposed to specific property. Second, attempts to identify a reason why the recipient's enrichment is unjust would unsettle well established principles in equity. Moreover, the primary justifications for the introduction of unjust enrichment are to avoid the uncertainty created by the fault requirement in knowing receipt and to enable a claim to be made against an unknowing recipient who has innocently dissipated trust property. However, fault will still be of central importance in claims for unjust enrichment in determining the availability of the change of position defence. Furthermore, any "injustice" created by the dissipation of trust property by an innocent recipient is already resolved through the personal liability of the trustee, not through the personal liability of the recipient. Third, in light of the lack of any need for unjust enrichment, it is further demonstrated that its introduction would impose an unnecessary burden on innocent recipients. ${ }^{2}$ It has been suggested that this consequence could possibly be mitigated by the introduction of the defence of change of position for proprietary claims to traceable proceeds. ${ }^{3}$ However, this would only serve to weaken the beneficiary's ability to recover specific property, undermining the wider scheme of enabling the recovery of trust property. The fourth reason is that the understanding of the equitable regime presented in this article provides the basis for a reappraisal of the Court of Appeal's decision in $R e$ Diplock. ${ }^{4}$ It is demonstrated in the penultimate section of this article that an executor does not generally owe a duty of preservation to legatees and that no proprietary claim should have been available in that case. The absence of a general duty of preservation explains the development

\footnotetext{
2 See text following note 141 below.

3 See text at note 158 below.

${ }^{4}$ Re Diplock [1948] Ch. 465 (CA).
} 
in equity of a strict liability personal claim. ${ }^{5}$ It is further demonstrated that a duty of preservation could arise in cases of deliberate misapplications by trustees, which explains the authorities where proprietary claims were available to recover testamentary assets. Importantly, these cases provided much of the early case law on knowing receipt. In short, the equitable regime only arises in response to a breach of a duty of preservation, and in such cases the underlying principle is to recover specific property which is assisted with a potential claim for knowing receipt against third parties. It is only in the absence of a duty of preservation where a strict liability personal claim can be made.

\section{The Equitable Regime And UnJust EnRichment}

\section{A. Proprietary and Personal Claims under the Equitable Regime}

At this stage, it will be useful to clarify the differences between the equitable regime and the unjust enrichment approach. Under orthodox trust principles, claims against third-party recipients can arise where they have received trust property as a result of a breach of duty by a trustee or fiduciary 6 (for the purposes of this article, where a fiduciary holds or receives identifiable property on behalf of another they are regarded as a "trustee"). ${ }^{7}$ Two types of claim are available in these circumstances. ${ }^{8}$ The first type of claim is a proprietary one and the second type of claim is a personal one.

The proprietary claim is generally regarded as the more desirable of the two as it offers practical benefits to litigants that are not provided by personal claims. ${ }^{9}$ These benefits include the ability to recover property even where the recipient is insolvent, as well as being able to bring claims against subsequent recipients. ${ }^{10}$ This proprietary claim does, however, have limits. A proprietary claim in equity will be defeated if the property has been received by a good faith purchaser of the legal title, ${ }^{11}$ and the claim can only attach to identifiable property either in the form of the original trust assets or where it is traced into substitutions. ${ }^{12}$ The ability

\footnotetext{
${ }^{5}$ See text to note 182 below.

${ }^{6}$ Williams v Central Bank of Nigeria [2014] UKSC 10; [2014] A.C. 1189, at [31], per Lord Sumption; and Brown v Bennett [1999] B.C.C. 525 (CA), 530, per Morritt L.J. Also, M. Conaglen and R. Nolan, "Contracts and Knowing Receipt: Principles and Application" (2013) 129 L.Q.R. 359, at 359-60.

${ }^{7}$ E.g. North American Land and Timber Co. Ltd. v Watkins [1904] 1 Ch. 242 (Ch), 250-51, per Kekewich J.

${ }^{8}$ Westdeutsche Landesbank Girozentrale v Islington L.B.C [1996] A.C. 669 (HL), 707-08, per Lord Browne-Wilkinson.

9 As noted in FHR European Ventures L.L.P. v Mankarious [2013] EWCA Civ 17; [2014] Ch. 1, at [14], per Lewison L.J.

10 Pennell v Deffell (1853) 4 De. G. M. \& G. 372, 388, per Turner L.J. In Relfo [2014] EWCA Civ 360, the court acknowledged that unjust enrichment can, in some circumstances, operate against indirect recipients.

${ }^{11}$ Burgess $v$ Wheate (1759) 1 Eden 177, 195, per Clarke M.R.

12 Re Diplock [1948] Ch. 465 (CA), 521, per Greene M.R.
} 
to trace into substitutions has proven contentious, with some academics arguing that rights to new property can only be explained on the basis of unjust enrichment. ${ }^{13}$ A major practical consequence of the unjust enrichment analysis of tracing is that it could potentially allow the recognition of an additional defence of change of position, which would allow the courts to take into account detriments suffered by an innocent recipient of trust property. ${ }^{14}$ In Foskett $v$ McKeown, the unjust enrichment analysis of tracing was rejected by the majority in the House of Lords and it was explained that the claim for traceable proceeds is based on the vindication of the beneficiary's property rights. ${ }^{15}$ The consequence is that no change of position defence applies to proprietary claims, ${ }^{16}$ a view that is shared in this article and which is developed further on. ${ }^{17}$

Alongside the proprietary claim, there is a potential personal claim in equity for knowing receipt (or "unconscionable receipt"). ${ }^{18}$ This personal claim for knowing receipt will be useful where the recipient no longer retains the traceable proceeds of the trust property, or where the property has depreciated in value. As the name indicates, a successful claimant must demonstrate that the defendant has received trust property and, in addition, has the required standard of knowledge that the property was received in breach of trust. ${ }^{19}$ The element of receipt can be established through the successful following or tracing of the trust property. ${ }^{20}$ However, this claim is only available where the recipient has received full "beneficial receipt" of the property, and will not be available where a third party receives trust property on behalf of the trustee. ${ }^{21}$ A more difficult issue is the degree of knowledge required to establish this form of liability. ${ }^{22}$ Some cases had indicated that constructive knowledge would suffice, ${ }^{23}$ whereas other cases required a state of mind which is closer to dishonesty. ${ }^{24}$ The only

13 P. Birks, "Receipt" in P. Birks and A. Pretto (eds.), Breach of Trust (Oxford 2002), 218; A. Burrows, The Law of Restitution, 3rd ed. (Oxford 2011), 169-70; R. Chambers, "Tracing and Unjust Enrichment" in J. Neyers, M. McInnes and S. Pitel (eds.), Understanding Unjust Enrichment (Oxford 2004), 272-76.

14 Although not necessarily; see L. Smith, "Unjust Enrichment, Property and the Structure of Trust" (2000) 116 L.Q.R. 412.

15 Foskett v McKeown [2001] 1 A.C. 102 (HL), 129, per Lord Millett.

16 E.g. Taylor v Blakelock (1886) 32 Ch. D. 560 (CA), 568, per Cotton L.J.: "anyone who took it from him simply as a volunteer could not say that he had any better title, and would still be bound by the trusts."

17 See text to note 163 below.

18 BCCI v Akindele [2001] Ch. 437 (CA), 455, per Nourse L.J.

19 Brown [1999] B.C.C. 525 (CA), 530, per Morritt L.J.

${ }^{20}$ El Ajou v Dollar Land Holdings [1994] 2 All E.R. 685 (CA), 700, per Hoffmann L.J.

21 Karak Rubber Co. Ltd. v Burden (No 2) [1972] 1 W.L.R. 602 (Ch), 632-33, per Brightman J.; Agip (Africa) Ltd. v Jackson [1990] Ch. 265 (Ch), 291-92, per Millett J.

22 See generally A. Duke, “The Knowing Receipt 'Knowledge' Requirement and Restitution's 'Good Faith' Change of Position Defence: Two Sides of the Same Coin?" (2010) 35 UWA Law.Rev. 49, 67-68.

23 E.g. Karak Rubber Co. Ltd. [1972] 1 W.L.R. 602 (Ch), 632, per Brightman J.; Belmont Finance Corp Ltd. v Williams Furniture Ltd. (No 2) [1980] 1 All E.R. 393 (CA), 405, per Buckley L.J.

24 E.g. Re Montagu's Settlement Trusts [1987] Ch 264 (Ch), 281, per Megarry V.C.; and Eagle Trust Plc v S.B.C. Securities Ltd. [1996] 1 B.C.L.C. 121 (Ch), 151, per Arden J. 
recurrent theme was that some degree of knowledge was required. ${ }^{25}$ At present, the solution preferred by the courts to this issue has been to adopt a test of "unconscionable" receipt, ${ }^{26}$ which provides a flexible approach that can be tailored depending on the context of the case before the court. This is also explored further on in this article. ${ }^{27}$

\section{B. Strict Liability Personal Claims in Common Law and Equity}

A claim for unjust enrichment is currently available against a recipient who is enriched at the expense of the claimant upon a recognised unjust factor with no available defence. ${ }^{28}$ A classic example of an unjust enrichment is where the claimant makes a mistaken payment. The receipt of such a payment traditionally only gives rise to a personal claim (although this issue itself is not without controversy, $)^{29}$ which can be satisfied by restitution of an equivalent value as opposed to the return of specific property. ${ }^{30}$ If a claim for unjust enrichment was available against a recipient of trust property, it would be necessary to identify an "unjust factor", with commentators focusing on the claimant's lack of consent or the trustee's lack of authority for making the transfer. ${ }^{31}$ This is distinct from the approach in knowing receipt which focuses on the conduct of the recipient. For this reason, unjust enrichment is commonly referred to as a form of strict liability, albeit one that has also been described as "fragile" due to the application of the change of position defence. ${ }^{32}$ This defence of change of position will be available where the recipient has, in good faith, changed their circumstances as a consequence of the enrichment and where the recipient would be worse off if they were required to make restitution. ${ }^{33}$

Additionally, equity recognises a strict liability personal claim, but only for the recovery of mistaken payments by those who are administering the estate of a deceased person. ${ }^{34}$ At present, unlike claims for unjust enrichment, recipients of such payments do not have the benefit of the change of position defence and can only escape personal liability if they stand as

25 Lord Nicholls, "Knowing Receipt: The Need for a New Landmark" in W.R. Cornish, R. Nolan, J. O'Sullivan and G. Virgo (eds.), Restitution: Past, Present and Future (Oxford 1998), 235-36.

${ }^{26} B C C I$ [2001] Ch. 437 (CA), 455, per Nourse L.J., as discussed in R. Nolan, "How Knowing Is Knowing Receipt?" [2000] C.L.J. 447. Also, Arthur v Attorney General of the Turks and Caicos Islands [2012] UKPC 30, at [33], per Sir Terence Etherton.

27 See the text following note 93 below.

28 Kleinwort Benson Ltd. v Lincoln City Council [1999] 2 A.C 349 (HL), 408-09, per Lord Hope.

29 The courts have so far resisted arguments that unjust enrichment gives rise to proprietary claims; Westdeutsche Landesbank Girozentrale [1996] A.C. 669 (HL), 708-09, per Lord Browne-Wilkinson; and Foskett [2001] 1 A.C. 102 (HL), 127, 129, per Lord Millett.

30 E.g. Case v Roberts (1817) Holt. N.P. 500, 501, per Burrough J.

31 Burrows, The Law of Restitution, pp. 403-08; P. Birks, An Introduction to the Law of Restitution, revised ed. (Oxford 1989), 140-46.

32 Birks, "Receipt", pp. 228-30.

33 A. Burrows, A Restatement of the English Law of Unjust Enrichment (Oxford 2012), 117.

34 Ministry of Health $v$ Simpson [1951] A.C. 251 (HL), 266, per Lord Simonds. 
a good faith purchaser. ${ }^{35}$ These claims are discussed in the final section of this article, where it is explained that they can be readily accommodated within an unjust enrichment analysis.

\section{Changing Attitudes towards the Availability of Unjust Enrichment for the Recovery of Trust Property}

Of central importance to this article is the argument that the equitable regime should be supplemented by a concurrent strict liability personal claim in unjust enrichment. ${ }^{36}$ An example is the Court of Appeal decision in Relfo $v$ Varsani, ${ }^{37}$ although it should be noted that a similar position has been set out in a number of lower court decisions. ${ }^{38}$ In Relfo, the claimant was seeking to recover money which had been transferred in breach of fiduciary duty to the defendant. The court concluded that the money could be traced into the hands of the defendant who had also knowingly received the property. ${ }^{39}$ However, it was also concluded that the claimant would have been able to succeed on the basis of unjust enrichment. It is notable that this discussion of unjust enrichment was unnecessary given that the grounds for knowing receipt had been established. According to Arden L.J., "[i]f a fiduciary steals trust money, the beneficiary can claim back the money, or any money or asset for which it has been substituted, from the person who has knowingly received it. A similar claim may be made in unjust enrichment". ${ }^{40}$ This statement is in direct conflict with an earlier Court of Appeal authority, BCCI v Akindele, where Nourse L.J. rejected the unjust enrichment analysis in the context of claims for the receipt of trust property. ${ }^{41}$ In Relfo, no acknowledgment was made of the controversy of introducing unjust enrichment alongside the equitable regime. The position adopted in Relfo indicates that the courts have yet to be fully convinced that unjust enrichment should not be concurrently available alongside the equitable regime. It is contended in the following section that the beneficiary's inability to bring an unjust enrichment claim cannot be solely explained by the recipient's security of receipt nor by the beneficiary's pre-existing equitable title. Instead, it will be explained that the equitable regime responds to the trustee's breach of their duty of preservation and this also provides a more convincing explanation as to

${ }^{35}$ Whale $v$ Booth (1784) 4 Doug. 36, 45, per Lord Mansfield.

36 Birks, "Receipt", pp. 228-30; C. Mitchell, P. Mitchell and S. Watterson (eds.), Goff \& Jones: The Law of Unjust Enrichment, 8th ed. (London 2011), 8-132. For views of the judiciary, see Lord Nicholls, "Knowing Receipt"; Lord Walker, "Dishonesty and Unconscionable Conduct in Commercial Life: Some Reflections on Accessory Liability and Knowing Receipt" (2005) 27 Sydney L.R. 187, at 202; Twinsectra $v$ Yardley [2002] 2 A.C. 164 (HL), at [105], per Lord Millett; and Dubai Aluminium Co. Ltd. v Salaam [2002] UKHL 48; [2003] 2 A.C. 366, at [87], per Lord Millett.

37 Relfo [2014] EWCA Civ 360.

${ }^{38}$ See the cases at note 1 above.

39 Relfo [2014] EWCA Civ 360, at [56]-[67], per Arden L.J.

${ }^{40}$ Ibid., at para. [1].

${ }^{41} B C C I[2001]$ Ch. 437 (CA), 455-56, per Nourse L.J. 
why beneficiaries cannot bring a claim for unjust enrichment against thirdparty recipients.

\section{Existing Approaches to the Equitable Regime}

\section{A. Security of Receipt}

One of the most commonly cited reasons for rejecting the availability of unjust enrichment in claims against recipients of trust property is the protection of the recipient's security of receipt. ${ }^{42}$ It is axiomatic that security of receipt is an important issue, and indeed it will be argued further on that unjust enrichment does not fully protect innocent recipients so it should only be available in the absence of any alternative means of recovery. ${ }^{43}$ However, the security of receipt issue does not, on its own, provide a compelling explanation for rejecting strict liability personal claims against recipients of trust property. The reason for this position is that it is difficult to see why security of receipt should not also preclude the application of strict liability personal claims in claims for unjust enrichment and the personal claim in Re Diplock. ${ }^{44}$ Moreover, if the primary justification for rejecting unjust enrichment was to protect security of receipt then, arguably, the aforementioned change of position defence should be recognised as an additional defence for recipients of trust property. But, as it will be argued below, ${ }^{45}$ the aim of recovering trust property transferred in breach of the trustee's duty would be undermined by the presence of the change of position defence. Although the security of receipt issue is undoubtedly a concern which prevents the overextension of the equitable regime, it does not provide the sole justification for the equitable regime as it currently stands.

\section{B. Title-Based Claims and Defective Transfers}

Another approach is provided by Smith, who contends that the basis of the proprietary and personal claims in equity is the claimant's continuing title to property which has reached the hands of the recipient. ${ }^{46}$ This distinguishes these cases from traditional unjust enrichment claims such as mistaken payments, where title is lost at the moment of transfer and the basis of the claim is a defective transfer. Under Smith's approach, strict liability personal claims only arise for defective transfers whereas the title of the

42 Smith, "Unjust Enrichment", pp. 431-34; G. Virgo, The Principles of the Law of Restitution, 3rd ed. (Oxford 2015), 653-54; G. Watt, "Personal Liability for Receipt of Trust Property: Allocating the Risks" in E. Cooke (ed.), Modern Studies in Property Law, vol. 3 (Oxford 2005), 97; J. Dietrich and P. Ridge, "The Receipt of What?': Questions Concerning Third Party Recipient Liability in Equity and Unjust Enrichment" (2007) 31 Melbourne U.L.Rev. 47, at 65-66.

43 See Section VI(A) below.

44 It has in fact been argued that the claim in Re Diplock should become a fault-based liability; Watt, "Personal Liability", p. 98.

45 See text to note 163 below.

46 Smith, "Unjust Enrichment", p. 416. 
beneficiary justifies treating those cases differently from defective transfer cases. Although it may appear that Smith's view is similar to the approach developed in this article, it is important to note that Smith's position seems to rely on the fact that a beneficiary has a pre-existing proprietary right which entitles them to make a proprietary claim. However, that does not seem to provide a sufficient distinction between claims under the equitable regime and claims for unjust enrichment. Jaffey, for example, contends that the core case of unjust enrichment, the mistaken payment, cannot be understood without reference to the claimant's initial title. ${ }^{47}$

The difficulty of distinguishing title-based claims and defective transfer claims on the basis of title can be further illustrated by considering the strict liability personal claim that is available for the recovery of mistaken transfers by executors. ${ }^{48}$ Smith has argued that this strict liability personal claim derives from the rights of the estate to recover overpayments, so that it is not a title-based claim but a defective transfer claim. ${ }^{49}$ This is debatable for two reasons. First, as Lord Davey explained in Harrison v Kirk, the equitable action was introduced to maintain the creditor or legatee's right of recovery against the estate after the courts began to protect executors when they had distributed assets under the decree of the court. ${ }^{50}$ If the executor has any right to bring a claim it is an extension of the creditor or legatee's pre-existing rights, not the other way around. ${ }^{51}$ Second, the claimant's pre-existing right to recover is nonetheless a type of property right, even though it might not be a full beneficial title. ${ }^{52}$ For these reasons, a preferable analysis would be one that explains the normative basis of the equitable right to make a title-based claim against a third party. As will be argued in this article, the title-based claim is dependent upon a breach of the trustee's duty to preserve identifiable property which, as will be demonstrated below, ${ }^{53}$ is absent where an executor makes a mistaken payment.

\section{The Incompatibility of the EQuitable Regime And UnJust ENRICHMENT}

The key to understanding the equitable regime is that it is a system which works for a coherent goal, which is the recovery of property transferred in

47 P. Jaffey, "Classification and Unjust Enrichment" (2004) 67 M.L.R. 1012, at 1024-25.

48 E.g. Re Diplock [1948] Ch 465 (CA).

49 Smith, "Unjust Enrichment", pp. 443-44.

50 Harrison v Kirk [1904] A.C. 1 (HL), 6-7; also Re King [1907] 1 Ch. 72 (Ch), 78-79, per Neville J. Early authorities, such as Harding $v$ Edge (1682) 1 Vern 143, broadly coincide with the development of the claim against overpaid legatees, e.g. Noel v Robinson (1682) 1 Vern 90.

${ }^{51}$ See also Re Diplock [1948] Ch. 465 (CA), 480, where Greene M.R. noted that the payments were mistakes of law, which at the time would have precluded any claims from the executors against the recipients.

52 Re Maye [2008] UKHL 9; [2008] 1 W.L.R. 315, at [17], per Lord Scott: "until the administration of the estates was complete, [the legatee] had no proprietary interest in any particular asset of the estates, his interest in their estates was none the less a proprietary interest."

53 See text to note 182 below. 
breach of the trustee's duty of preservation. Unjust enrichment relies on "weaker" justifications for restitution such as where the claimant has made a conscious decision to make a transfer but their intent was vitiated or conditional. For this reason unjust enrichment only provides for restitution of the value of an enrichment, as opposed to the recovery of specific property. The result is that unjust enrichment cannot provide any assistance in the recovery of property transferred in breach of the trustee's duty, and in fact the conflicting rationale of unjust enrichment would only serve to weaken the possibility of recovering specific property.

\section{A. Recovering Property}

In the preceding section, it was explained that the claimant's right to recover property from third parties cannot be differentiated from unjust enrichment merely on the basis of the claimant's original property rights. Nonetheless, this analysis does not deny that beneficiaries do have proprietary rights in trust property. Whilst the property remains under the control of the trustee, the beneficiary has a superior right to the property and will enjoy priority over the trustee's creditors. ${ }^{54}$ But it does not necessarily follow that the right to recover property from a third party is the same right that exists where the property is still in the hands of the trustee or fiduciary. ${ }^{55}$ This approach requires a modification of Virgo's analysis that such claims arise through the vindication of property rights, ${ }^{56}$ which was also adopted in Foskett $v$ McKeown. ${ }^{57}$ Whilst the claim is still one which vindicates the claimant's property rights, the precise cause of action is the trustee's wrongdoing.

The wrongdoing which unlocks the door to the beneficiary's right to bring a direct claim to recover property under the equitable regime is the failure of the trustee to retain control over trust property, ${ }^{58}$ in breach of their duty to preserve the beneficiary's interests in identifiable property. A duty of preservation is normally created when an express trustee or fiduciary accepts to hold identifiable property subject to the beneficiary or principal's interests. ${ }^{59}$ This duty can also be imposed, as in resulting or constructive trusts where the trustee is placed under "an obligation to

54 F.W. Maitland, Equity: A Course of Lectures, 2nd ed. (Cambridge 1936, repr. 2011), 112. E.g. Re Strachan (1876) 4 Ch. D. 123 (CA).

55 Birks used a similar argument to explain cases where the claimant had a pre-existing legal proprietary interest, and a new equitable proprietary right is created. This is not a continuation of the original property right; P. Birks, "Property and Unjust Enrichment: Categorical Truths" (1997) New Zealand L.Rev. $623,643-44$.

${ }^{56}$ G. Virgo, "What Is the Law of Restitution About?" in Cornish et al., Restitution.

${ }^{57}$ Foskett [2001] 1 A.C. 102 (HL), 115 per Lord Hoffmann, 118 per Lord Hope and 129 per Lord Millett.

58 Attorney General v The Earl of Chesterfield (1854) 18 Beav. 596, 599-600, per Sir John Romilly.

59 E.g. Hamilton v Wright (1842) 9 Cl. \& F. 111, 122, per Lord Brougham: "[w]hen he afterwards accepted the trust, it became his duty as trustee to do nothing for the impairing or destruction of the trust.” Also Harrison v Rowley (1798) 4 Ves. Jr. 212, 215-16, per Arden M.R. 
deal with property in a particular way on behalf of another person". ${ }^{60}$ The recurrent theme is that a duty of preservation will only arise where the trustee has knowledge that they hold identifiable property on behalf of a beneficiary. ${ }^{61}$ This duty will be breached where the trustee makes an unrestricted transfer and can no longer preserve the beneficiary's interests in the transferred property. ${ }^{62}$ Accordingly, the beneficiary's right to recover trust property from a third-party recipient is best seen as a secondary right which, arguably, creates a new property right where the property is no longer subject to the control of the trustee. ${ }^{63}$ The beneficiary's secondary right replicates the performance of the beneficiary's primary rights as closely as possible. Thus, the proprietary claim achieves what the trustee can no longer do; it preserves the beneficiary's interests in identifiable property by enabling the beneficiary to recover specific property. This also explains why claimants can recover substitutions made by innocent recipients. Lord Millett has argued that the trustee has a duty to preserve the beneficiary's interests in identifiable property, and this primary duty can be enforced whenever the trustee substitutes the original property for new assets. ${ }^{64}$ Since the secondary right replicates performance of the primary right, the ability to recover traceable proceeds of trust property in the hands of a third party operates in the same way. As Bramwell L.J. explained in Re Smith, Fleming, \& Co., the beneficiary should not be prevented from tracing into substitutions merely as a result of the trustee's breach of their duty. ${ }^{65}$

Ho has contended that the accounting process can be used to explain rights to recover property from third parties as directly enforcing the trustee's primary duty. ${ }^{66}$ But the duty is not simply for the beneficiary's interests to be preserved in identifiable property. It is a personal duty which must be performed by the trustee, and if a trustee makes an unrestricted transfer they can no more control what happens with the trust property than any other transferor who advances property to another person. ${ }^{67}$

${ }^{60}$ Staden v Jones [2008] EWCA Civ 936, at [25], per Arden L.J. E.g. Clarke v Ramuz [1891] 2 Q.B. 456 (CA), 459-60, per Lord Coleridge C.J.

${ }^{61}$ S. Gardner, "Moment of Truth for Knowing Receipt?" (2009) 125 L.Q.R. 20, at 23.

${ }^{62}$ See Salway v Salway (1831) 2 Russ. \& M. 215, 219-20, per Brougham L.C.

63 R. Nolan also contends that rights to recover property from third parties are secondary rights, "Equitable Property" (2006) 122 L.Q.R. 232. A similar proposition is made by H.F. Stone, "The Nature of the Rights of the "Cestui Que Trust"' (1917) 17 Colum.L.R. 467, at 476, although Stone denies that the beneficiary's rights are proprietary.

${ }^{64}$ P. Millett, "Proprietary Restitution" in S. Degeling and J. Edelman (eds.), Equity in Commercial Law (Sydney 2005), 315-17; Taylor v Plumer (1815) 3 M. \& S. 562, 574, per Lord Ellenborough C.J.

65 E.g. Re Smith, Fleming, \& Co. (1879) 11 Ch. D. 306, 316, per Bramwell L.J.

${ }^{66}$ L. Ho, "An Account of Accounts" (2016) 28 Sing.A.L.J. 849, at 855. See also C. Mitchell and S. Watterson, "Remedies for Knowing Receipt" in C. Mitchell (ed.), Constructive and Resulting Trusts (Oxford 2010).

${ }^{67}$ See Goddard v Carlisle (1821) 9 Price 169, 179, per Richards L.C.: "this instrument could not be affected, if it were shewn to be a mere voluntary deed proceeding purely from the unbiassed act of the party; because every one has a right to dispose of his own property, in any way in which he may think fit, however foolishly he may act in so doing; and this Court cannot disturb such disposition." 
Moreover, as Swadling has noted, merely because a claim to recover property from a third party appears to duplicate a claim to recover property from a trustee does not mean that they are analytically the same. ${ }^{68}$ Indeed, there are important reasons for recognising the distinction between proprietary claims to recover property where it is retained by the trustee and claims to recover property from a third party. The proposition that a beneficiary does not have a primary right to recover property from third parties is in line with the general pattern in equity where the beneficiary's primary rights are against the trustee, and it is the trustee who has the power to bring claims against third parties. ${ }^{69}$ For example, in Field $v$ Field, the beneficiary sought to prevent a trustee from leaving deeds in the hands of solicitors. ${ }^{70}$ This request was refused as appropriate steps had been taken by the trustees to ensure that the solicitors had safeguarded the property. It is only where the trustee retains control over the property in the hands of a third party that it will still be possible for the beneficiary to enforce their primary rights. ${ }^{71}$

Whether the beneficiary is asserting their primary or secondary rights will be important for two reasons. First, no limitation period applies where property is retained by a third party who holds property on behalf of the trustee, ${ }^{72}$ whereas claims to recover property from a third party who receives unrestricted control of property are subject to a limitation period. ${ }^{73}$ Second, third parties who hold trust property on behalf of trustees will only be liable for dishonest assistance. This will be the case even where the third party has knowledge that they have received trust property in breach of other trust obligations. ${ }^{74}$ A knowing receipt claim can only arise where the trustee has lost control over trust property and has breached their duty of preservation. This is because a party who knowingly receives unrestricted control over trust property has an unfettered choice to assist in the recovery of trust property whereas a solicitor or bank, who is acting under the instructions of the trustee, may be liable for breaching a separate duty to the trustee if they refuse to act in accordance with these instructions. ${ }^{75}$

68 W. Swadling, "The Fiction of the Constructive Trust" (2011) 64 C.L.P. 399, at note 79.

${ }^{69}$ Hayim v Citibank [1987] A.C. 730 (PC), 748, per Lord Templeman.

${ }^{70}$ Field $v$ Field [1894] 1 Ch. 425 (Ch), 428-29, per Kekewich J. Also, Re De Pothonier [1900] 2 Ch. 529 (Ch).

71 Which means that a beneficiary can still recover trust property either by bringing the trust to an end, or by bringing a derivative claim on behalf of the trustee where the trustee is not properly exercising control over the third party.

72 E.g. Soar v Ashwell [1893] 2 Q.B. 390 (CA), as noted in Williams [2014] UKSC 10; [2014] A.C. 1189, at [75], per Lord Neuberger.

73 Williams, ibid., at [36], per Lord Sumption. Also, P. Smith and R. Davern "I Want My (Equitable) Property Back: Time Limits on Recovering Trust Property from Innocent Volunteers" (2015) 21 Trusts \& Trustees.

74 Re Blundell (1888) 40 Ch D 370 (Ch); Brinsden v Williams [1894] 3 Ch 185 (Ch).

75 Gray v Johnston (1868) L.R. 3 H.L. 1, 14, per Lord Westbury. Also Hartga v The Bank of England (1796) 3 Ves. Jr. 55; Nickolson v Knowles (1820) 5 Madd. 47, cited with approval in Carl Zeiss Stiftung v Herbert Smith \& Co. (No 2) [1969] 2 Ch. 276 (CA), 299, per Sachs L.J. 


\section{B. The Personal Claim for Knowing Receipt}

Like the proprietary claim, the purpose of knowing receipt is to facilitate the recovery of misapplied trust property. Knowing receipt does this by imposing a duty on knowing recipients to assist in the recovery of trust property. ${ }^{76}$ This duty is, however, distinguishable from the trustee's duty of preservation. As explained by Swadling, a third-party recipient may become subject to a "duty to convey" property to the beneficiary whereas a trustee is subject to a "duty to hold" property. ${ }^{77} \mathrm{We}$ can only expect a recipient to be under a duty to convey the property where they have sufficient knowledge that the property was received in breach of the trustee's duty of preservation. ${ }^{78}$

In contrast to the view adopted here, Mitchell and Watterson have argued that the duty of the knowing recipient mirrors the express trustee's duty to account. ${ }^{79}$ These authors take the view that the recipient is under a "primary restorative duty", but that there is no need to show that the recipient breached any duty. ${ }^{80}$ They cite Green $v$ Weatherill as an example, where it was concluded that an account could be requested against a knowing recipient without an allegation of breach. ${ }^{81}$ There are two reasons for departing from Mitchell and Watterson's analysis. The first reason is that even if a knowing recipient is subject to the same duty as a trustee, it is questionable whether a trustee can be held personally liable in the absence of a breach of duty. An account is merely a process, ${ }^{82}$ and this process does not provide an explanation as to why the trustee should be liable where the trust property has been lost. $^{83}$ Mitchell has argued that the trustee owes a primary duty to provide substitutive performance in the form of a debt for any shortfall. ${ }^{84}$ But the beneficiary does not have a primary right to a non-specific asset in the form of a debt, as it is a fundamental principle of trust law that there must be identifiable property. ${ }^{85}$

Instead it is arguably the loss of the trust property, in breach of the duty of preservation, which provides the basis for the trustee's personal liability. For example, in Re Swan a trustee was held liable to account for the destruction

76 Arthur [2012] UKPC 30, at [37], per Sir Terence Etherton; Mitchell et al., Goff \& Jones, 8-199.

77 Swadling, "The Fiction", p. 409.

78 See the reasoning of S. Smith, "A Duty to Make Restitution" (2013) 26 Can. J.L. and Juris. 157, 17374. A similar duty to help recover trust property is imposed on co-trustees where they are "fixed with knowledge" that a fellow trustee is misapplying trust property, e.g. Brice v Stokes (1805) 11 Ves. Jr. 319, 327, per Eldon L.C.

79 Mitchell and Watterson, "Remedies for Knowing Receipt", pp. 135-36.

80 Ibid., at p. 136. Also Lord Millett, "Equity's Place in the Law of Commerce" (1998) 114 L.Q.R. 214, at 225 .

81 Green v Weatherill [1929] 2 Ch. $213(\mathrm{Ch}), 222$, per Maugham J.

82 See L. Smith, "The Duties of Trustees in Comparative Perspective" (2016) 24 Eur.Rev.Priv.L. 1031, at [14]: "[t]he obligation to account is an obligation to provide information."

83 S. Worthington, "Four Questions on Fiduciaries" (2016) 2 Canadian Journal of Comparative and Contemporary Law 723, who notes the term accounting "does not illuminate, explain or justify what goes on", at 764 .

84 C. Mitchell, "Equitable Compensation for Breach of Fiduciary Duty" (2013) 66 C.L.P. 307, at $322-23$.

85 See R. Chambers, "Liability" in Birks and Pretto, Breach of Trust, p. 4. E.g. Angove's Pty Ltd. v Bailey [2016] UKSC 47; [2016] 1 W.L.R. 3179, at [29], per Lord Sumption. 
of jewellery. ${ }^{86}$ According to Sargant J., the point in time when the trustee is liable to account is when they commit a breach of trust as "the right of the cestui que trust which was first violated was a right to the property itself". ${ }^{87}$ This can be seen to operate in a similar way to the principle of res ipsa loqitor, ${ }^{88}$ as the very fact that the trust property has been lost will infer that, on the balance of probabilities, the trustee has breached their obligation. ${ }^{89}$ In turn, when Maugham J. stated in Green v Weatherill that there can be an account without proof of a breach of duty, this may simply mean that it will be inferred that the knowing recipient has breached their duty where they no longer retain the trust property. ${ }^{90}$ The second reason is that, even if one accepts that a trustee can be held personally liable in the absence of any breach of duty, ${ }^{91}$ extending this reasoning to a third-party recipient is more difficult. As Chambers has noted, knowledge alone is not a very convincing reason for imposing personal liability upon a third-party recipient. ${ }^{92}$ For this reason, it is appropriate to recognise that it is the recipient's breach of their duty to convey the property which gives rise to personal liability.

The concept of unconscionability provides two important functions in, first, identifying the degree of knowledge required for the imposition of this duty and, second, identifying when the duty has been breached. In relation to the first point, unconscionability enables the courts to recognise that different levels of enquiry may be appropriate depending on the context of the defendant's receipt. ${ }^{93}$ It may be appropriate to find constructive knowledge in transactions involving land, which can be "leisurely investigated", but not in commercial transactions where no such opportunity arises. ${ }^{94}$ Second, unconscionability also enables the courts to take into account the defendant's conduct in determining whether the recipient has indeed breached their duty. ${ }^{95}$ Take, for example, a defendant who discovers that they

${ }^{86}$ Re Swan [1915] 1 Ch. 829 (Ch).

${ }^{87}$ Ibid., at p. 836 .

88 E.g. Ng Chun Pui v Lee Chuen Tat [1988] R.T.R. 298, 300-01, per Lord Griffiths.

89 See J. Eichengrun, "Remedying the Remedy of Accounting" (1985) 60 Ind.L.J. 463, 470. But it will not be conclusive, as where trust property is stolen, e.g. Jones v Lewis (1751) 2 Ves. Sen. 240.

90 Green [1929] 2 Ch. 213 (Ch). Notably, it was accepted that the defendant retained trust property, and Maugham J. went on to conclude that "an account against her is therefore unnecessary", at 222. See also Chambers, "Liability", p. 7.

91 Eaves v Hickson (1861) 30 Beav. 136 is commonly cited as an authority, e.g. Mitchell and Watterson, "Remedies for Knowing Receipt", p. 126. In contrast, Giffard L.J. in Re Biddulph (1868-69) L.R. 4 Ch. App. 280 (CA) stated "I do not think it less a breach of trust because it has happened that the persons entitled under the trusts were not known", which would suggest that the facts of Eaves did constitute a breach of duty.

92 See R. Chambers, "The End of Knowing Receipt" (2016) 2 Canadian Journal of Comparative and Contemporary Law 1 , at 7.

${ }^{93}$ BCCI [2001] Ch 437 (CA), 453-55, per Nourse L.J. A point also made by Watt, "Personal Liability".

94 Manchester Trust $v$ Furness [1895] 2 Q.B. 539, 545, per Lindley L.J., cited with approval in BCCI, ibid., at p. 455 , per Nourse L.J.

95 E.g. Armstrong D.L.W. GmbH v Winnington Networks Ltd. [2012] EWHC 10 (Ch); [2013] Ch. 156, at [277]-[286], per Morris Q.C. It is also notable that Lord Walker in Yeoman's Rowe Management Ltd. $v$ Cobbe [2008] UKHL 55; [2008] 1 W.L.R. 1752, at [92], argued that unconscionability "should always be used [] as an objective value judgment on behaviour". 
have innocently received trust property, but the property is stolen by someone else before the property can be restored. A trustee would not be held personally liable in such circumstances, ${ }^{96}$ and it would be inappropriate to impose a more onerous duty on a third party than the duty of a trustee who has accepted their position. ${ }^{97}$

\section{The Conflicting Aims of Unjust Enrichment}

In light of the analysis in the preceding section, the most obvious reason for rejecting the application of unjust enrichment is that a claim for unjust enrichment fails to replicate the primary right of the beneficiary which relates to identifiable property. Unlike the equitable regime, unjust enrichment focuses on reversing the abstract enrichment of the recipient, but this does not require restitution of the original property or its traceable proceeds. ${ }^{98}$ The introduction of the unjust enrichment analysis would actually undermine the premise of the equitable regime by sending the message to recipients that restoration of identifiable trust property does not determine the question of their personal liability. It may be argued that the introduction of unjust enrichment would at least deter recipients from deliberately dissipating the trust property, as this would normally exclude the protection afforded by the change of position defence. ${ }^{99}$ But any recipient who seeks to deprive the claimant of trust property would in any case be liable under the claim for knowing receipt, and they would not be made "more liable" by the availability of a concurrent claim for unjust enrichment.

There are good reasons for the different approaches of the equitable regime and unjust enrichment. Whereas the equitable regime is designed to recover what has been lost by the trustee's breach of duty, the law of unjust enrichment is designed for dealing with "not-wrongs". ${ }^{100}$ This means that the law of unjust enrichment does not provide strong enough justifications to allow recovery of specific property. For example, the traditional basis of a claim for unjust enrichment is that the claimant has intended to make an outright transfer but their intention was deficient, such as where the enrichment arises as a result of mistakes or failed conditions. ${ }^{101}$ The conscious decision to transfer property in these cases means that the recipient will receive unrestricted dominion over the enrichment. ${ }^{102}$

96 Morley v Morley (1678) 2 Ch. Cas. 2; Jones (1751) 2 Ves. Sen. 240; Job v Job (1877) 6 Ch. D. 562 (Ch).

97 See Re Blake [1932] 1 Ch. 54 (Ch), at 62-63, per Maugham J. Also P.J. Millett, "Restitution and Constructive Trusts" (1998) 114 L.Q.R. 399, at 403-06.

98 P. Birks, Unjust Enrichment, 2nd ed. (Oxford 2005), 69-70.

99 E.g. E. Bant, The Change of Position Defence (Oxford 2009), 217, argues that the change of position defence has a prophylactic aim.

100 This phrase is taken from P. Birks, "Rights, Wrongs, and Remedies" (2000) 20 O.J.L.S. 1, at $27-28$.

101 Birks, An Introduction, p. 140; and also Birks, Unjust Enrichment, pp. 116-17.

102 E.g. Goddard (1821) 9 Price 169, 179, per Richards L.C. Beneficiaries will also lack the right to recover property where they are responsible for transfers to third parties; Re Horne [1905] $1 \mathrm{Ch} .76(\mathrm{Ch}), 81$, per Warrington $\mathrm{J}$. 
Therefore, claimants lose their right to recover specific property and unjustly enriched recipients are only obliged to make restitution of an equivalent sum.

It must be noted that there are some situations where proprietary claims are increasingly available in cases that have been categorised as instances of unjust enrichment. For example, Lord Browne-Wilkinson in Westdeutsche Landesbank Girozentrale v Islington L.B.C. concluded that interests in stolen money would be protected under a constructive trust. ${ }^{103}$ Moreover, cases of fraud are commonly dealt with using equitable principles, either in the form of a trust or "mere equities" in the form of rescission. ${ }^{104}$ However, as this author has previously argued there is a very different principle which underpins the application of the equitable regime in cases of unauthorised transfers or where money is obtained through deception. ${ }^{105}$ Claims that are based purely on unjust enrichment will normally only give rise to a strict liability personal claim, but a trust can be imposed (along with a duty to preserve property) where a recipient has stolen property or fraudulently induced a transfer. ${ }^{106}$ Notably, just as under the equitable regime, whenever the claimant enjoys rights under such a trust they will also be precluded from bringing an unjust enrichment claim against subsequent recipients. ${ }^{107}$ Claims to recover trust property and claims for unjust enrichment should, therefore, be seen as mutually exclusive. ${ }^{108}$

\section{The Absence of Any Need for the Introduction of UnJust ENRICHMENT}

The preceding section has demonstrated that unjust enrichment does not assist in the recovery of trust property. In this section it is argued that there are no convincing justifications for the introduction of unjust

103 Westdeutsche Landesbank Girozentrale [1996] A.C. 669 (HL), 715-16, per Lord Browne-Wilkinson.

104 El Ajou v Dollar Land Holdings Plc [1993] 3 All E.R. 717 (Ch), 734, per Millett J.; Shalson v Russo [2003] EWHC 1637 (Ch); [2005] Ch. 281, at [122]-[124], per Rimer J.; London Allied Holdings Ltd. v Lee [2007] EWHC 2061 (Ch), at [276], per Etherton J. Also discussed in B. Hacker, "Proprietary Restitution after Impaired Consent Transfers: A Generalised Power Model" [2009] C.L.J. 324.

105 D. Salmons, "The Availability of Proprietary Restitution in Cases of Mistaken Payments" [2015] C.L.J. 534. 'This previous article touched on a number of the key issues which have been more thoroughly explored, and some of which have been revised, in the current article, but the core argument in the previous article still stands.'

106 Ibid., at pp. 547-48; and Lord Browne-Wilkinson in Westdeutsche Landesbank Girozentrale [1996] A. C. 669 (HL), 716. Another approach is to simply conclude that the claimant enjoys continuing property rights in these cases; Virgo, The Principles, pp. 572-73.

107 E.g. Bank of America v Arnell [1999] Lloyd's Rep. Bank 399 (QB), discussed at text to note 132 below. Also Salmons, "The Availability", pp. 561-62.

108 Although Lipkin Gorman v Karpnale Ltd. [1991] 2 A.C. 548 (HL) may be cited as contradicting this position, Virgo points out that the claim involved the assertion of common law property rights, The Principles, pp. 560-61. Also see Duke, "The Knowing Receipt", pp. 58-59. Indeed, in Lipkin at 572 , Lord Goff implied that claims to recover common law property and claims to recover trust property were mutually exclusive. 
enrichment in claims against third-party recipients of trust property. There are three reasons for this position. First, it is not possible to identify an "unjust" factor that does not conflict with settled principles of trusts law. Second, unjust enrichment fails to provide greater clarity in personal claims against recipients of trust property. Third, the perceived injustice of innocent recipients who retain benefits derived from dissipated trust property is resolved through the personal liability of the trustee.

\section{A. The Search for an Unjust Factor}

First, it is difficult to identify a reason why the enrichment of a third party is "unjust" which does not conflict with the wider operation of the law of trusts. If the unjust factor was "ignorance" that would undermine the whole premise of recognising that it is the trustee who has control and power over trust property. ${ }^{109}$ There are many acts of which the beneficiary is "ignorant" of, or even may object to, but the trustee still has power to do. ${ }^{110}$ An alternative is to focus on "absence of basis" but, to borrow an argument from Worthington, the trustee undoubtedly does have the legal power to transfer legal title which provides a clear basis even for deliberate misapplications by the trustee. ${ }^{111}$

A final possibility is that there is a lack of authority. ${ }^{112}$ However, if the claimant is merely basing the claim on the premise of a lack of authority, this alone cannot be sufficient to enable a claim for unjust enrichment. To return to the example given earlier, ${ }^{113}$ a trustee might lack authority to give property to a third party but they nonetheless retain control over the trust property. In such circumstances, the beneficiary will be precluded from bringing any personal claim against a third party unless that third party has dishonestly assisted in a breach of duty. ${ }^{114}$ If a claim for unjust enrichment could arise on the basis of a lack of authority, it would mean that any third party who receives property on behalf of a trustee could be liable even in the absence of dishonesty, as the change of position defence would be precluded where the recipient has knowledge. ${ }^{115}$ To avoid the conclusion that all third-party recipients of trust property would find

109 Burgess (1759) 1 Eden 177, 218: "Trusts, from the nature of the thing, may be left to the honour and faith of the trustee" (per Lord Mansfield).

110 See R. Chambers and J. Penner, "Ignorance" in S. Degeling and J. Edelman (eds.), Unjust Enrichment in Commercial Law (Sydney 2008), 257.

111 S. Worthington, Equity, 2nd ed. (Oxford 2006), 185. E.g. Lord Selbourne in Barnes v Addy (1873-74) L.R. 9 Ch. App. 244 (CA), 251: "[t]hose who create a trust clothe the trustee with a legal power and control over the trust property." Also Burgess (1759) 1 Eden 177, 246, per Lord Mansfield: "[i]t is most certain, that every man who creates a trust puts his estate into the power of his trustee"; and Thomson v Clydesdale Bank Ltd. [1893] A.C. 282 (HL), 291, per Lord Shand.

112 Chambers and Penner, "Ignorance", pp. 260-63.

113 See text following note 74 above.

114 E.g. Maw v Pearson (1860) 28 Beav. 196, 199-200, per Romilly M.R.

115 The change of position defence will be precluded if the recipient has knowledge, e.g. Jones $v$ Churcher [2009] EWHC 722 (QB); [2009] 2 Lloyd's Rep. 94. 
themselves potentially liable under unjust enrichment, it has been argued that a third party is only "enriched" where they obtain "beneficial receipt" of trust property. ${ }^{116}$ However, Hood has pointed out that third parties may be enriched regardless of whether they receive property "beneficially". ${ }^{117}$ For example, banks use customer deposits to fund their profit making activities. Indeed, both Burrows and Mitchell have conceded that receiving banks would often find themselves open to liability under unjust enrichment, subject to the change of position defence. ${ }^{118}$ But this would represent a radical expansion of the potential liability of banks. This is not simply an issue which concerns security of receipt. The courts of equity traditionally provided higher levels of protection to third parties who held property on behalf of trustees. This is because, according to Selborne L.C. in Barnes $v A d d y$, if such recipients were open to strict liability personal claims it would discourage third parties from providing their services to trustees. ${ }^{119}$ As Shadwell V.C. explained in Lockwood v Abdy, "in cases where gentlemen act as trustees, they must, of necessity, employ solicitors, receivers, bankers, and agents of various kinds". ${ }^{120}$ If unjust enrichment was available on the basis that the trustee lacked authority to transfer property to the recipient, it would impede the ability of all trustees to carry out their duties effectively.

\section{B. The Difficulties with the Fault Requirement}

Second, as noted earlier, ${ }^{121}$ the most contentious issue relating to knowing receipt has been the degree of knowledge required to establish the claim. ${ }^{122}$ Accordingly, Lord Nicholls argued extra-judicially that the solution would be to provide beneficiaries with a personal claim under a form of strict liability subject to the change of position defence. ${ }^{123}$ The purported attraction of this proposal would be that it would remove the fault requirement from the question of liability. ${ }^{124}$ Nevertheless, the question of the defendant's fault would still be a central issue in most claims for unjust enrichment. Indeed, Virgo notes that the result in most cases will be the same whether personal liability rests on knowing receipt or unjust enrichment. ${ }^{125}$

\footnotetext{
116 R. Stevens, "Why Do Agents Drop Out?" (2005) L.M.C.L.Q. 101, 110-11.

117 P. Hood, Principles of Lender Liability (Oxford 2012), [8.187-8.190]; and Uzinterimpex J.S.C. v Standard Bank Plc [2008] EWCA Civ 819, at [39], per Moore-Bick L.J.

118 Burrows, The Law of Restitution, pp. 427-28; C. Mitchell, "Assistance" in Birks and Pretto, Breach of Trust, pp. 184-85.

119 Barnes (1873-74) L.R. 9 Ch. App. 244 (CA), 252.

120 Lockwood v Abdy (1845) 14 Sim. 437, 441.

121 See the text to note 22 above.

122 E.g. Birks, "Receipt", pp. 226-27.

123 Lord Nicholls, "Knowing Receipt", pp. 233-34, 238.

124 Ibid., at pp. 236, 238 .

125 Virgo, The Principles, p. 655. E.g. Barclays Bank Plc [2010] EWHC 1383, at [74], per Proudman J.; MGN Ltd. [2009] EWHC 1680 (QB); [2009] All E.R. 99 (Eng), at [4], [36], per Tugendhat J.; Re Hampton Capital Ltd. [2015] EWHC 1905 (Ch), at [67], per George Bompas Q.C.; and Dyson Technology Ltd. v Curtis [2010] EWHC 3289 (Ch), at [129], per David Grant J.
} 
This is because the defence of change of position will only be available in circumstances where the defendant has acted in good faith. ${ }^{126}$ Courts will still need to consider the extent of the recipient's knowledge under the requirement of good faith in every case where the third party seeks to defend against a claim for unjust enrichment. Moreover, the term "unconscionability" is increasingly being used to define good faith in the context of the change of position defence. ${ }^{127}$ In fact, it has been explicitly stated that it would not be "desirable to attempt to define the limits of good faith" as the courts have looked to maintain a similar degree of flexibility that has been developed in the context of knowing receipt claims. ${ }^{128}$ The proposition that unjust enrichment would remove the difficulties in defining the fault requirement for establishing the personal liability of third-party recipients cannot be sustained.

\section{Continuing Enrichment}

Third, it has been contended that the absence of a claim for unjust enrichment would lead to great injustice where an innocent recipient is still financially better off despite no longer retaining misapplied property ("continuing enrichment"). ${ }^{129}$ This is because, as noted above, ${ }^{130}$ unjust enrichment focuses on the abstract wealth of the recipient rather than the retention of the original property or its traceable proceeds. ${ }^{131}$ An example will demonstrate the point. In Bank of America $v$ Arnell, one of the defendants had innocently received $£ 25,750 .{ }^{132}$ The payment had been received from a fraudster who convinced the recipient that this was a legitimate transaction. ${ }^{133}$ As part of the arrangement with the fraudster, the recipient retained $£ 750$ of the received funds. ${ }^{134}$ The defendant subsequently spent this money "on various items as part of her general living expenses". ${ }^{135}$ It was concluded that she was an innocent recipient, which precluded any possible claim for knowing receipt. But if unjust enrichment had been available in Arnell, the defendant would have still been unjustly

126 Lipkin Gorman [1991] 2 A.C. 548 (HL), 579-80, per Lord Goff.

127 Niru Battery Manufacturing Co. v Milestone Trading Ltd. (No .1) [2003] EWCA Civ 1446; [2004] Q.B. 985, at [156]-[157], per Clarke L.J. More recently, Webber v Department for Education [2014] EWHC $4240(\mathrm{Ch})$, at [62], per Nugee J.

128 Niru Battery Manufacturing Co. [2002] EWHC 1425 (Comm); [2002] 2 All E.R. (Comm) 705, at [135], per Moore-Bick J. S. Barkehall-Thomas "Change of Position, Good Faith and Unconscionability" in M. Bryan (ed.), Private Law Theory and Practice (London 2007), 289.

129 Birks, "Receipt", p. 236; Burrows, The Law of Restitution, pp. 424-31; T. Akkouh and S. Worthington, "Re Diplock (1948)" in C. Mitchell and P. Mitchell (eds.), Landmark Cases in the Law of Restitution (Oxford 2006), 297.

130 See text to note 98 above.

131 Birks, "Receipt", p. 236.

132 Bank of America [1999] Lloyd's Rep. Bank 399 (QB).

133 Ibid., at paras.[16]-[17], per Aikens J.

134 This arrangement could have provided the basis for a good faith purchaser defence but this possibility was not explored. For the purposes of the example, this is treated as a voluntary payment.

135 Bank of America [1999] Lloyd's Rep. Bank 399 (QB), at [4.7]. 
enriched at the claimant's expense by the receipt of the $£ 750$ whether or not she retained any traceable proceeds as she had spent the money "in the ordinary course of things". ${ }^{136}$

The problem with any perceived "injustice" created by the result in Arnell is that it overlooks the fact that it is the trustee who bears sole responsibility for the loss of the property by making an unrestricted transfer to the innocent recipient in the first place. ${ }^{137}$ Therefore, the loss of trust property by an unknowing third party should be resolved through the personal liability of the trustee. As stated by Romilly M.R. in Browne v Butter, "if a trustee so deals with a trust fund as to allow a third party to obtain the control over it, whereby it is afterwards lost, he becomes liable for a breach of trust by acting beyond the scope of his authority". ${ }^{138}$ Admittedly, in some cases, it may not be possible to successfully sue the trustee. ${ }^{139}$ For example, the trustee may lack the funds to provide compensation. But the inability of a wrongdoer to pay compensation is an unconvincing reason for imposing liability on an innocent party. ${ }^{140}$ Another possibility is that the trustee may be protected by an exclusion clause. Nonetheless, if that is the case, this is a risk that the settlor will have accepted and there cannot be any complaint if this risk eventuates. There is simply no need to impose liability for continuing enrichment, as any losses which result from the dissipation of the trust property by an innocent recipient should be exclusively governed by the trustee's liability.

\section{The Position of Third Parties}

The final reason for rejecting the introduction of unjust enrichment for claims to recover trust property is that it would provide an unfair burden on innocent recipients. Any expansion of liability will introduce additional risks for innocent recipients and the change of position defence does not ensure sufficient protection. In fact, even supporters of the unjust enrichment approach have conceded that the concurrence of a strict liability personal claim and the existing proprietary claim in equity would be unfairly prejudicial to innocent recipients unless further protection is afforded to those who retain misapplied property. ${ }^{141}$ But this would result in the overall weakening of the equitable regime as a means of recovering misapplied property.

\footnotetext{
136 Lipkin Gorman [1991] 2 A.C. 548 (HL), 580, per Lord Goff.

137 E.g. Clough v Bond (1838) 3 My. \& C. 490.

138 Browne v Butter (1857) 24 Beav. 159, 161-62.

139 Akkouh and Worthington, "Re Diplock (1948)", p. 298.

140 As it is in other areas of private law, e.g. International Energy Group Ltd. v Zurich Insurance plc [2015] UKSC 33; [2016] A.C. 509: "[i]nsurers have deep pockets, but that in itself cannot justify imposing on them a liability which they have not agreed", at [171], per Lord Hodge.

141 E.g. Birks, "Receipt", p. 221; and Burrows, The Law of Restitution, p. 547.
} 


\section{A. Innocent Recipients and Continuing Enrichment}

If an unjust enrichment claim is available against a recipient of trust property, much will rest on the operation of the change of position defence. It is argued here that the change of position defence does not ensure sufficient protection for innocent recipients. There are two reasons why unjust enrichment will place an unwelcome burden on innocent recipients; the first relates to the bargaining power of litigants, and the second relates to the difficulties of establishing precisely how the enrichment has been lost. In regard to the first reason, the classification of knowledge as part of the cause of action or the defence is important in showing who has the burden of proving the recipient's state of mind. ${ }^{142}$ Whereas in knowing receipt the burden of proving the knowledge of the recipient is imposed on the claimant, in unjust enrichment the defendant has the burden of proving good faith. ${ }^{143}$ This may seem like a subtle distinction, but it should not be assumed that it is an insignificant one. As Smith has noted, "[a]lthough there may be no difference in the classroom between fault-based liability and strict liability with defences, there is a great difference in the courtroom". ${ }^{144}$ By placing the burden on the defendant it is more likely that a defendant would seek to minimise the risks of litigation by agreeing to make restitution, even when they have a strong argument that they have changed their position. ${ }^{145}$

The second reason is that the recipient is required to demonstrate their innocent state of mind and also that the loss of the enrichment was due to an extraordinary expenditure. ${ }^{146}$ In regard to the recipient's state of mind, it has been argued by Kiri that the burden of proof should be placed on the recipient as they are the party that will be better placed to supply this evidence. ${ }^{147}$ But the difficulties in proving the recipient's state of mind are not insurmountable, ${ }^{148}$ and, given the potentially onerous nature of personal liability for the receipt of trust property, it is appropriate that the claimant has the burden of proving the recipient's state of mind. Also, proving that an expenditure was "extraordinary" is often far from an easy task. Phillip Collins Ltd. $v$ Davis provides a good example. ${ }^{149}$ In Phillip, the

${ }^{142}$ K. Low, "Recipient Liability in Equity" (2008) R.L.R 96, at 105; Law Society v Habitable Concepts Ltd. [2010] EWHC $1449(\mathrm{Ch})$, at [15], per Norris J.

${ }^{143}$ Re Polly Peck (No 3) (CA, 17 March 1993), section 8, per Hoffmann L.J. Also Polly Peck International Plc v Nadir (No 2) [1992] 4 All E.R .769 (CA), 781-82, per Scott L.J.

144 Smith, "Unjust Enrichment", p. 434.

145 C. Harpum, "Knowing Receipt: The Need for a New Landmark: Some Reflections" in Cornish et al., Restitution, p. 250.

146 Lipkin Gorman [1991] 2 A.C. 548 (HL), 580, per Lord Goff; Test Claimants in the FII Group Litigation $v$ Revenue and Customs Commissioners [2014] EWHC 4302 (Ch), at [353], per Henderson J.

147 N. Kiri, "Recipient and Accessory Liability: Where Do We Stand Now" (2006) 21 J.I.B.L.R. 611, at 614.

148 The courts have been prepared to draw an inference of knowledge even in the absence of direct evidence, as in Agip (Africa) Ltd. [1990] Ch. 265 (Ch), 293-95, per Millett J.

149 Phillip Collins Ltd. v Davis [2000] 3 All E.R. 808 (Ch). Also Virgo, The Principles, p. 690. 
defendants had received overpayments but were trying to argue that they had changed their position. To establish the change of position defence, these defendants were required to demonstrate that they had altered their circumstances in relation to periodical overpayments over six years. Parker J. concluded that he was "unable to find that any particular item of expenditure was directly referable to the overpayments of royalties". ${ }^{150}$ A pragmatic conclusion was reached whereby the defendants were entitled to a defence of $50 \%$ for the sums received due to their change in lifestyle, ${ }^{151}$ but even this solution does not guarantee that an innocent party will not be unfairly burdened.

The predicament of the defendants in Phillip provides a stark illustration of the difficulties that may be faced by defendants in establishing the defence of change of position. Although Burrows has contended that courts should not require defendants "to account precisely for how they" spend enrichments, ${ }^{152}$ there is no guarantee that defendants will find that all judges will show similar pragmatism. For example, in the more recent case of MGN Ltd. $v$ Horton, Tugendhat J. indicated that a defendant would need to provide a full account of any expenditure by demonstrating that each expenditure was attributable to the enrichments. ${ }^{153}$ A further concern is that the courts may take an unduly narrow approach to the types of detriment that will be relevant under this defence. In Scottish Equitable v Derby, the Court of Appeal rejected the change of position defence despite the fact that, because of an overpayment, the recipient had "begun to accustom himself to a standard of living and a level of security beyond his true means". ${ }^{154}$ As Dietrich and Ridge have noted, strict liability subject to the change of position defence is "potentially oppressive in all cases". ${ }^{155}$ This is unavoidable in traditional unjust enrichment scenarios as the claimant lacks any other means of recovering the enrichment. But, given that the beneficiary's rights are sufficiently protected by their ability to recover trust property and their right to sue the trustee, the addition of unjust enrichment simply adds an unnecessary risk for innocent third parties of trust property.

\section{B. The Potential Impact on the Proprietary Claim}

Even if one takes the view that the change of position defence does provide sufficient protection for innocent recipients, it would still be necessary to reconsider the scope of the existing proprietary claim for the recovery of

\footnotetext{
150 Philip Collins Ltd., ibid., at p. 829.

151 See also Burrows, The Law of Restitution, pp. 535-36.

152 Ibid., at p. 535.

153 MGN Ltd. [2009] EWHC (QB) 1680; [2009] All E.R. 99 (Eng), at [33]. See also J. Edelman, "The Change of Position Defence: A Defence of Unjust Disenrichment" (2012) 92 B.U.L.Rev. 1009, at 1013.

154 Scottish Equitable v Derby [2001] EWCA Civ 369; [2001] 3 All E.R. 818, at [52], per Brown L.J.

155 Dietrich and Ridge, "The Receipt of What?", p. 83.
} 
trust property. This is because any recipient who had changed their position would still be left worse off if they retained any traceable proceeds of the trust property. It is notable that Lord Millett advocated the unjust enrichment analysis for the personal liability of third-party recipients, but rejected the application of the change of position defence in claims which were contingent upon tracing. ${ }^{156}$ By contrast, some of the strongest supporters of the unjust enrichment analysis have recognised that a personal claim for unjust enrichment alongside the existing proprietary claim in equity would offer too much protection for beneficiaries to the detriment of innocent recipients. ${ }^{157}$ For this reason, Birks argued that the change of position defence should also be available for those who retain the traceable proceeds of trust property. ${ }^{158}$ Burrows has also argued that the failure to harmonise the personal and proprietary claims would allow claimants to "outflank the change of position defence". ${ }^{159}$ According to Bryan, this would create "tactical opportunities" and he describes this as an "undesirable outcome". 160

A first point to mention is that it is commonly accepted by authors such as Birks and Burrows that proprietary claims to recover the original property are not examples of unjust enrichment. ${ }^{161}$ These authors have, instead, argued that unjust enrichment underpins proprietary claims where the property is traced into substitute assets. This means that the introduction of the change of position defence for those who retain the traceable proceeds of trust property would only provide a partial solution to the overburdening of recipients. For those innocent recipients who retain the original property, the claimant would still have the choice of pursuing a proprietary claim which is not subject to the change of position defence as well as a strict liability personal claim in unjust enrichment. ${ }^{162}$ If the central justification for recognising the change of position defence in proprietary claims against third parties is that the claimant could circumvent its operation in personal claims, this outcome is inevitable where the recipient retains the original property.

The second point is that, even if we ignore the plight of innocent recipients who retain the original trust property, the availability of the change of position defence in claims for the recovery of the traceable proceeds of trust property would only serve to reduce the chances of recovering misapplied

156 Millett, "Proprietary Restitution", p. 325. The defence was rejected in Foskett [2001] 1 A.C. 102 (HL), 129, per Lord Millett.

157 Birks, "Receipt", p. 221; and Burrows, The Law of Restitution, p. 547.

158 Birks, ibid., at pp. 221, 238.

159 Burrows, The Law of Restitution, p. 547.

160 M. Bryan, "The Criteria for the Award of Proprietary Remedies: Rethinking the Proprietary Base" in Bryan, Private Law Theory and Practice, p. 282.

161 Birks, "Receipt", p. 216; Burrows, The Law of Restitution, p. 169.

162 Birks, "Property and Unjust Enrichment", p. 653: "[t]he rational way forward is therefore for equity to back up its vindicatio with obligations born of wrongs and obligations born of unjust enrichment." 
property. The point is made effectively by Fox, who explains that "it would erode the security of property if vindicatory actions could be defeated by questions about the justice of the defendant's being required to make full restitution". ${ }^{163}$ This provides a decisive reason for rejecting the change of position defence in proprietary claims against third parties. In short, unless the courts are going to make substantial changes to the proprietary claim by weakening the beneficiary's rights to recover misapplied property, the introduction of a personal claim for unjust enrichment would impose a burden on innocent recipients which cannot be justified.

\section{Applying this Analysis to Re Diplock}

The simple conclusion to be drawn from the discussion so far is that it is inappropriate to afford claimants rights to bring strict liability personal claims in addition to rights to recover specific property. This analysis can be further illustrated by returning to the line of authorities that preceded the decision in Re Diplock. ${ }^{164}$ In Re Diplock, the Court of Appeal concluded that it was possible for general legatees to bring proprietary claims, in addition to strict liability personal claims, against the recipients of mistaken payments by the executors. ${ }^{165}$ It is important to deal with this case as Re Diplock is the only clear authority to support the proposition that it is possible to have a strict liability personal claim as well as an equitable proprietary claim on the same set of facts. ${ }^{166}$ However, as it will be demonstrated, ${ }^{167}$ the personal claim in Re Diplock was developed as a strict liability claim for the recovery of abstract wealth, and the proprietary claim recognised by the Court of Appeal in that case lacked support in principle and authority.

There are three reasons for reaching this conclusion. The first reason is that the mistaken payments represented a "devastavit" which is a waste of assets by the executor but which is also distinct from a trustee's breach of their duty to preserve trust property. ${ }^{168}$ The second reason is that the authorities before Re Diplock precluded the general availability of a proprietary claim to recover payments made under devastavit. ${ }^{169}$ The third reason is that the courts would allow a proprietary claim only where an executor knew that the transfer would prejudice those entitled

\footnotetext{
163 D. Fox, "Legal Title as a Ground of Restitutionary Liability" [2000] R.L.R. 465, at 488.

164 Re Diplock [1948] Ch. 465 (CA).

165 Ibid., at pp. 556-57.

166 Ibid., at pp. 556-57. Following this decision, there were a number of cases which accepted the possibility that Re Diplock could be applied against recipients of trust property; G.L. Baker Ltd. v Medway Building and Supplies Ltd. [1958] 1 W.L.R. 1216 (Ch), 1220, per Danckwerts J.; Eddis v Chichester Constable [1969] 1 W.L.R. 385 (Ch), 388, per Goff J.; Butler v Broadhead [1975] Ch. 97 (Ch), 108, per Templeman J.; Re J. Leslie Engineers Co. Ltd. [1976] 1 W.L.R. 292 (Ch), 299, per Oliver J.

167 See the text to note 187 below.

168 Bahin v Hughes (1886) 31 Ch. D. 390 (CA), 393, per Cotton L.J.

169 See text after note 194 below.
} 
under the estate. ${ }^{170}$ These cases of misapplications provided a number of the early authorities for the development of the knowing receipt claim against third parties. ${ }^{171}$ The development of this fault-based liability demonstrates that the strict liability personal claim did not co-exist alongside the claim to recover specific property from third parties.

\section{A. The Nature of the Legatee's Rights}

There are a number of reasons for questioning the basis of the proprietary claim in Re Diplock. In Re Diplock, the main authorities relied on to establish the proprietary claim for the mistaken payments were the decisions in Re Hallett's Estate and Sinclair v Brougham, and neither case concerns the availability of proprietary responses in the administration of estates. ${ }^{172}$ Only five other authorities were referenced in the Court of Appeal's discussion of the proprietary claim, but only one of those authorities, Re Blake, related to claims for testamentary property. ${ }^{173}$ It was even noted by Greene M.R. that Re Blake ruled out the possibility of a proprietary claim against third parties. ${ }^{174}$ Moreover, Akkouh and Worthington have pointed out that the court's reliance upon Sinclair is questionable in light of modern judicial treatment of the reasoning applied in Sinclair. ${ }^{175}$

There were two limbs to the court's reasoning that a proprietary claim was available in Re Diplock and both reveal that the reasoning was flawed. First, it was stated that claimants can trace in equity where there is a fiduciary duty or an existing proprietary interest. ${ }^{176}$ Second, as the legatees enjoyed a type of equitable proprietary interest, a proprietary claim was available. ${ }^{177}$ With regard to the first proposition, the question of whether one can trace, which is the question that the court asked in Re Diplock, is not the same as asking whether the claimant has a proprietary claim. ${ }^{178}$ Tracing is merely a process and it does not establish a right to recover property. ${ }^{179}$ Furthermore, it is indeed correct that the presence of a fiduciary duty can be an important factor in identifying the availability

\footnotetext{
${ }^{170}$ E.g. Hill $v$ Simpson (1802) 7 Ves. Jr. 152.

171 C. Harpum, "The Stranger as Constructive Trustee: Part 2" (1986) 102 L.Q.R. 267, 273.

172 Re Hallett's Estate (1880) 13 Ch. D. 696 (CA); Sinclair v Brougham [1914] A.C. 398 (HL).

173 The authorities discussed in the decision were: Banque Belge v Hambrouck [1921] 1 K.B. 321 (CA); In re Guardian Permanent Benefit Building Society (1882) 23 Ch. D. 440 (CA); Devayne v Noble (Clayton's Case) (1816) 1 Mer. 572; Re Stenning [1895] 2 Ch. 433 (Ch); Re Blake [1932] 1 Ch. 54 (Ch).

174 Re Diplock [1948] Ch. 465 (CA), 544, per Greene M.R.; Re Blake [1932] 1 Ch. 54 (Ch), 63-64, per Maugham J.

175 Akkouh and Worthington, "Re Diplock (1948)", p. 304. Much of the reasoning in Sinclair was effectively overruled by the House of Lords in Westdeutsche Landesbank Girozentrale [1996] A.C. 669 (HL), as discussed in Haugesund Kommune v Depfa A.C.S. Bank [2010] EWCA Civ 579; [2012] Q.B. 549, at [65]-[80], per Aikens L.J.

176 Re Diplock [1948] Ch. 465 (CA), 520.

177 Ibid., at p. 530.

178 L. Smith, The Law of Tracing (Oxford 1997), 11-14.

179 Foskett [2001] 1 A.C. 102 (HL), 113 per Lord Steyn, 120 per Lord Hope and 128 per Lord Millett.
} 
of a proprietary claim against a third party. However, it is not simply the presence of a fiduciary duty which is important in establishing proprietary claims against third parties, but that the position of the fiduciary must entail a duty of preservation in relation to identifiable property. For example, an agent is a fiduciary but the principal would have no proprietary claim if the agent is permitted to mix the proceeds of a sale of property with their own. ${ }^{180}$ For the second proposition, it has been demonstrated earlier in this article that even beneficiaries do not have a general right to bring a direct claim to recover trust property from a third party. ${ }^{181}$ There must in fact be a transfer made in breach of the duty of preservation in relation to identifiable property.

The problem in Re Diplock is that, whilst an executor owes a duty to preserve the general wealth of the estate for creditors or legatees, ${ }^{182}$ this does not constitute a duty to preserve interests in identifiable property for any particular beneficiary. ${ }^{183}$ This is because, during administration, the executor will not necessarily know who is entitled to the assets. ${ }^{184}$ As explained by Viscount Radcliffe in Commissioner of Stamp Duties v Livingston, "until administration was complete no one was in a position to say what items of property would need to be realised for the purposes of that administration or of what the residue, when ascertained, would consist or what its value would be". ${ }^{185}$ Even in cases where a specific legacy is left to a legatee, until the executor assents, the legatee does not have title in relation to any specific property. ${ }^{186}$

\section{B. The Strict Liability Personal Claim in Re Diplock}

The executor's position is also important in understanding the personal claim in Re Diplock. The personal claim works on the basis that the creditors or legatees have a right to satisfaction from the assets of the estate, which may be lost where assets have been received by a third party under a mistaken payment by an executor. This is demonstrated by the rule that no claim for repayment could be made against an overpaid

${ }^{180}$ Henry $v$ Hammond [1913] 2 K.B. 515, 521, per Channell J. It may be different if the agent has acted fraudulently; In re Hindmarsh (1860) 1 Drew. \& Sm. 129, 132, per Kindersley.

181 See text to note 71 above. That does not prevent a derivative claim, as in Soar [1893] 2 Q.B. 390 (CA), where the beneficiary recovered property on behalf of the trustee. But the executors would not have had standing themselves to bring a proprietary claim where they had acted under a mistake of law.

182 Dr Barnardo's Homes v Special Income Tax Commissioners [1921] 2 A.C. 1 (HL), 8, per Viscount Finlay.

183 Executors are not, strictly speaking, subject to duties as trustees; e.g. Dacre v Patrickson (1860) 1 Drew. \& Sm. 182, 185, per Kindersley V.C.: "[q]uâ executor, he cannot have a trust imposed upon him by the will."

184 Johnson v Newton (1853) 11 Hare. 160, 167-69, per Page Wood V.C.

185 Commissioner of Stamp Duties v Livingston [1965] A.C. 694 (PC), 708, per Viscount Radcliffe.

186 Mead v Lord Orrery (1745) 3 Atk. 235, 238, per Lord Hardwicke. Also Attenborough v Solomon [1913] A.C. 76 (HL), 83, per Viscount Haldane. 
recipient when a shortfall arises after the overpayment. ${ }^{187}$ Therefore, the claimant only has standing to bring a claim on the basis that a reduction in the wealth of the estate is attributable to the transfer to the recipient. In this way, the strict liability personal claim is an appropriate means for recovery as it reflects the primary rights of the creditors and legatees during administration, which is protected by the executor's duty to preserve the value of the estate as opposed to a duty to preserve identifiable property. This personal claim could be assimilated under an unjust enrichment analysis, with the unjust factor being the "deprivation of assets for the distribution of the estate". ${ }^{188}$

This raises the question of whether the change of position defence should be similarly available for these claims. There is early authority which indicates that hardships suffered by recipients are not taken into account by the court, such as David v Frowd. ${ }^{189}$ But this must be placed in context. When the courts of equity began to permit the release of legacies without requiring security, 190 this was on the basis that "everybody taking a residue must know that he takes it subject to the testator's liabilities, and takes the risk of its afterwards turning out that there are undiscovered liabilities". ${ }^{191}$ According to modern authorities, taking the risk that there could be an obligation to return an enrichment would preclude the availability of the change of position defence. ${ }^{192}$ It can be argued that it is no longer the case that all recipients of mistaken payments by executors will be aware they may be required to repay, and it would be fictional for the courts to ignore evidence presented by recipients that they were unaware of this risk. Furthermore, in principle, it seems that the courts always had the power to take into account hardships suffered by recipients. For example, in Johnson v Johnson, Lord Alvanley explained that a common law claim for money had and received (the precursor to the modern law of unjust enrichment) was not permitted against the recipient of a mistaken payment by an executor, as it was only in equity where the court could take into account "the mode in which the funds might have been applied", otherwise "great injustice may arise". ${ }^{193}$ There is, therefore, a compelling case for the application of the change of position defence, which was yet to be developed at the

${ }^{187}$ Re Diplock [1948] Ch. 465 (CA), 487-88, 493-95; Orr v Kaines (1751) 2 Ves. Sen. 194; Peterson v Peterson (1866-67) L.R. 3 Eq. 111 (Ch).

188 Similar phrasing was used in Re Diplock [1948] Ch. 465 (CA), 503-04.

189 David v Frowd (1833) 1 My. \& K. 200, 211, per Leach M.R.

190 See Jewon v Grant (1677) 3 Swans. 659, 660, per Lord Nottingham.

191 Jervis $v$ Wolferstan (1874) L.R. 18 Eq. 18, 26-27, per Jessel M.R. Also Prowse v Spurgin (1867-68) L.R. 5 Eq 99, 102, per Romilly M.R., where it was noted that a legatee enters into "an undertaking, not expressed, but clearly understood according to the practice of the Court, that he will repay the amount, if any, by which he has been overpaid".

192 E.g. Goss v Chilcott [1996] A.C. 788 (PC), 799, per Lord Goff.

193 Johnson v Johnson (1802) 3 Bos. \& P. 162, 169. Also Blake v Gale (1886) L.R. 32 Ch. D. 571, 580, per Cotton L.J.: "the right of the creditors to proceed against the residuary legatees is simply a right given by equity in order that justice may be done." 
time of Johnson and Re Diplock, to ensure that claims to reverse transfers of abstract wealth which result from mistakes by executors are treated with the same degree of justice as similar claims in unjust enrichment.

\section{The Absence of Proprietary Claims in Cases of Mistake}

The incompatibility of this strict liability personal claim alongside claims to recovery specific property is reflected in the dearth of support for the availability of a proprietary claim in the cases that preceded Re Diplock. In cases of mistaken payments by executors, the courts would provide the legatee or creditor with the personal claim, with no mention of any proprietary claim. ${ }^{194}$ Admittedly, there are some instances where the language used by the courts seemed to indicate a proprietary response. For example, in many of the cases it was stated that the legatee or creditor could "follow" the property into the hands of the recipient. ${ }^{195}$ Nevertheless, as noted in the latest edition of Williams, Martyn and Sunnocks, this simply meant that a personal claim could be made against the recipient. ${ }^{196}$ The phrase "follow the assets" normally referred to the type of situation that Birks described as "leapfrogging", whereby a claimant seeks to establish a personal claim against indirect recipients. ${ }^{197}$ An ability to bring a claim against an indirect recipient does not necessarily demonstrate the presence of a proprietary right and the language of "following the assets" tells us little about the nature of the claim. More telling is the fact that the claim was generally regarded as a personal one, as revealed by Lord Cottenham L.C.'s statement in March $v$ Russell where it was explained that a claimant's interest in overpaid assets is protected by "the personal liability of the legatee". ${ }^{198}$

There are at least some authorities to support the availability of a proprietary claim in this context, with the strongest example being Brooksbank $v$ Smith. ${ }^{199}$ But on closer analysis, this case is quite distinct from Re Diplock. In Brooksbank, the defendant had received shares on the basis that the executors had been informed his wife had survived the testatrix when in fact she had not. It was held that there was a specific lien on behalf of the legatees. A significant factor in this case appeared to be that the executors had been misinformed of the survival of the defendant's wife. The case was treated as one that was comparable to fraud for limitation purposes and it is entirely possible that the basis of the case is closer to the earlier mentioned situations where a trust is imposed on a party who obtains property

\footnotetext{
194 E.g. in David (1833) 1 My. \& K. 200, 206, where counsel for the defendants explained that the claim was not for any specific property but rather "something equivalent to a fund".

195 E.g. Newman v Barton (1690) 2 Vern. 205. See also Law of Property Amendment Act 1859, s. 29.

196 J.R. Martyn and N. Caddick (eds.), Williams, Martyn and Sunnocks: Executors, Administrators and Probate, 20th ed. (London 2015), [83-02].

197 Birks, Unjust Enrichment, pp. 86-89; and also considered in Relfo [2014] EWCA Civ 360, at [95]-[96], per Arden L.J.

198 March v Russell (1837) 3 My. \& C. 31, 42, per Cottenham L.C.

199 Brooksbank v Smith (1836) 2 Y. \& C. Ex. 58.
} 
by deception. ${ }^{200}$ Another authority is West $v$ Roberts where the mistaken recipient of shares was ordered to return them in specie. ${ }^{201}$ The claim succeeded on the basis that the claimant was a specific legatee and that there had been an assent by the executors. ${ }^{202}$ An assent gives the legatee full legal title to the property and Swinfen Eady J. recognised that, in the absence of an assent, the legatee would not have any general right to demand the return of the shares. ${ }^{203}$ Therefore, the case is actually an authority for the proposition that the proprietary claim should not have been available in Re Diplock as the executors had not assented and neither were the claimants specific legatees.

A further example is Noble $v$ Brett where a creditor sought to recover money from the legatees. ${ }^{204}$ In Noble, the residuary legatee was insolvent but the executors retained property as trustees for the other legatees. Romilly M.R. seemed to accept that "the right of the creditor and that of the executor to attach the fund itself is limited to the case where the executor or the Court has not parted with the control over it". ${ }^{205}$ Similarly, in Dibbs $v$ Goren, a lien was imposed but only in relation to funds which were still under the control of the executors. ${ }^{206}$ Once more, this undermines the conclusion in Re Diplock, where the property was no longer retained by the executors or the court and was instead under the control of the recipients. It is also worth noting that, in Noble, no enquiry was made whether any of the money was retained by the residuary legatee. If a proprietary claim had been available, this would have enabled the creditor to also recover from the recipient. ${ }^{207}$ Likewise, in Todd $v$ Studholme, the essential issue was that a number of creditors had been overpaid, but part of the money could not be recovered due to the insolvency of some of the recipients. ${ }^{208}$ Once more, no attempt was made to identify any remaining property in the hands of the insolvent recipients. Sir Page Wood V.C. even noted that no lien attached to property purchased under an equitable mortgage as the personal right to recover from the other recipients meant that the claimant's "remedy is already ample". 209

Finally, claimants who sought to recover overpayments were denied the practical benefits that would have attached to proprietary claims. In Jervis $v$ Wolferstan, claims for overpayments were restricted to the original value received, and it was not possible to "recover any of the income". ${ }^{210}$

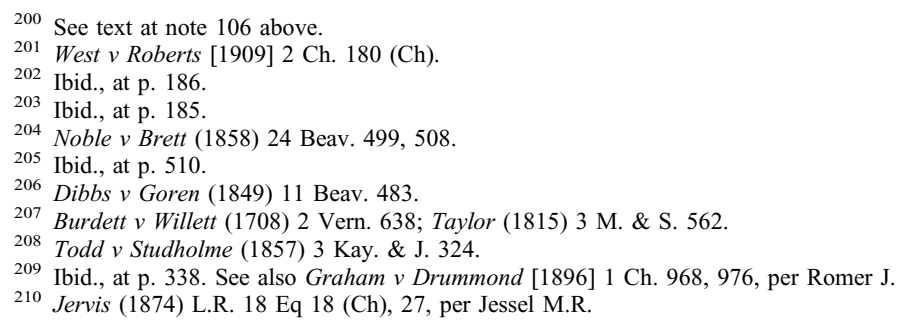


Similarly, in Gittins $v$ Steele it was concluded that interest could only be recovered where the court held property but not where assets had been received by legatees. ${ }^{211}$ Although the position today is that the courts have wider powers to recover interest for personal claims, ${ }^{212}$ this was not the case at the time of these decisions. ${ }^{213}$ Since this was the core issue in Gittins $v$ Steele, it seems odd that the claimants pursued interest under a strict liability personal claim when interest would have readily been available for a proprietary claim. The only logical conclusion is that it was generally recognised that no proprietary claim was possible alongside the strict liability personal claim.

\section{Proprietary Claims for Wrongdoings by Executors and Recipients}

There were, however, certain situations where a proprietary claim would become available. It was noted earlier that the knowledge and actions of a legal owner can justify the imposition of a trust, along with a duty of preservation, in relation to identifiable property. ${ }^{214}$ Similarly, a duty of preservation would be imposed where the executor misapplied property knowing that it would deprive the assets of the estate from those who were entitled as creditors or legatees. ${ }^{215}$ As a result, proprietary claims could be made to recover these transfers. Such cases are clearly distinct from the circumstances of Re Diplock, where the transfer was made under a genuine, albeit mistaken, belief that the recipients were entitled to the property. In Nugent $v$ Gifford, it was stated that property could not generally be followed "as specifick assets" where it had been transferred by an executor, but that "[ $\mathrm{t}] \mathrm{his}$ court will indeed follow assets upon voluntary alienations by collusion of the executor". ${ }^{216}$ Similarly, in Harford $v$ Lloyd the executor misapplied property by making a transfer to a third party who invested the money into securities and the beneficiary was permitted a charge over the securities. ${ }^{217}$ A further example is Midgley $v$ Midgley, where the executor had made a payment to the recipient's solicitor for a debt against the estate despite being aware that the debt was not recoverable. ${ }^{218}$ The claimants recovered the money under a proprietary claim. ${ }^{219}$

There are also those cases where the recipient had obtained property through deception and this justified the imposition of a trust which in

\footnotetext{
211 Gittins $v$ Steele (1818) 1 Swans. 199, 200, per Eldon L.C.

212 Sempra Metals Ltd. v I.R.C. [2007] UKHL 34; [2008] 1 A.C. 561.

213 As noted by Greene M.R. in Re Diplock [1948] Ch. 465 (CA), 517. E.g. Moons v De Bernales (1826) 1 Russ. 301, 306, per Lord Gifford.

214 See text to note 106 above. E.g. Mead (1745) 3 Atk. 235, 238-40, per Lord Hardwicke.

215 Docker v Somes (1834) 2 My. \& K. 655, 665, per Brougham L.C.

216 Nugent v Gifford (1738) 1 Atk. 463, 463-64, per Lord Hardwicke; and Crane v Drake (1708) 2 Vern. 616.

217 Harford v Lloyd (1855) 20 Beav. 310, 321, per Sir John Romilly. The same principle applied to powers of appointment; Townshend $v$ Windham (1750) 2 Ves. Sen. 1, 10-11, per Lord Hardwicke.

218 Midgley $v$ Midgley [1893] 3 Ch. 282 (Ch), affd (CA).

219 Ibid., at p. 290 , per Romer J.
} 
turn enabled a claim to recover the transferred property. ${ }^{220}$ As noted above, ${ }^{221}$ Brooksbank $v$ Smith would fall within this scenario and another example is Consett $v$ Bell, where the recipient had deceived the executor into making a payment that was not due under the will. ${ }^{222}$ The court in Consett recognised that the claimant would have the right to recover specific property in this type of situation. ${ }^{223}$ In both Brooksbank and Consett, the claimant's proprietary rights can be justified by the imposition of a trust, along with a duty of preservation, against those who fraudulently induce transfers. This fits with a number of clear judicial statements which recognised that executors had the right to make dispositions of property, and to give the recipient good title, unless the recipient had acted in bad faith. ${ }^{224}$ This may appear to simply reflect the operation of the good faith purchaser defence, however it is implicit that the word "disposition" includes distributions to volunteers. ${ }^{225}$ Moreover, whereas the burden of demonstrating good faith under the good faith purchaser defence is placed on the defendant, ${ }^{226}$ the burden of proving bad faith in claims to recover specific property received from an executor was clearly placed on the claimant. ${ }^{227}$

Probably the most revealing aspect of the case law concerning deliberate misapplications of property, as opposed to non-induced mistakes, is that these cases provide the early foundations of the knowing receipt action. As Harpum stated, "[m]any of the principles of liability for knowing receipt were developed in relation to improper dispositions by executors". 228 This would have been an unnecessary development if the strict liability personal claim was available against these recipients. ${ }^{229}$ For example, it was stated in Keane $v$ Robarts that "[e]very person who acquires personal assets by a breach of trust, or devastavit in the executor, is responsible to those who are entitled under the will, if he is a party to the breach of trust". ${ }^{230}$ Another example is Rolfe $v$ Gregory where the executor used testamentary property to pay a debt in circumstances where the recipient was aware of the misapplication of the property. ${ }^{231}$ There was no consideration in

${ }^{220}$ Under this analysis, these claimants enjoyed primary rights against the recipients as constructive trustees.

221 See text to note 199 above.

222 Consett $v$ Bell (1842) 1 Y. \& C. Ch. 569.

223 Ibid., at pp. 578-79, per Sir Knight Bruce.

224 E.g. Hill (1802) 7 Ves. Jr. 152, 166, per Grant M.R.; Farr v Newman (1792) 4 Term. Rep. 621, 630, per Grose J.

225 See Grey v I.R.C. [1960] A.C. 1 (HL), 13, per Viscount Simonds, for the meaning of "disposition".

226 Papadimitriou v Crédit Agricole Corpn and Investment Bank [2015] UKPC 13; [2015] 1 W.L.R. 4265, at [33], per Lord Sumption.

227 Corser v Cartwright (1874-75) L.R. 7 H.L. 731 (HL), 738, per Cairns L.C.; Richardson v Horton (1843) 7 Beav. 112, 125, per Langdale M.R.

228 Harpum, "The Stranger", p. 273.

229 See C. Harpum, "The Basis of Equitable Liability" in P. Birks (ed.), The Frontiers of Liability (Oxford 1994), 24.

230 Keane $v$ Robarts (1819) 4 Madd. 332, 357, per Leach V.C.

231 Rolfe v Gregory (1865) 4 De. G. J. \& S. 576 (Ch), 579, per Lord Westbury. Also Scott v Tyler (1788) Dick. 712, 724-25, per Lord Thurlow. 
these cases whether the recipient should have been strictly liable. The only logical conclusion is that, as with the general pattern of the equitable regime, the proprietary claim precludes the application of any strict liability personal claim.

\section{CONCLUSION}

The aim of the equitable regime is to assist in the recovery of misapplied property where the trustee has breached their duty of preservation, and this aim underpins the proprietary and personal claims in equity. If the courts are going to impose strict liability personal claims on innocent recipients under the principle of unjust enrichment, there needs to be compelling reasons for doing so. But it has been demonstrated that the reasons for this development are unconvincing. First, by focusing on the abstract wealth of the recipient, it has been demonstrated that the unjust enrichment approach does not support the aim of recovering misapplied property. Second, there is no clear justification for the introduction of unjust enrichment alongside the equitable regime. It has not been possible to find an "unjust factor" which does not create conflict with well settled rules in equity. Neither does unjust enrichment resolve the difficulties of establishing the requisite fault element, as it merely recreates them at the defences stage. Moreover, any injustice created by the continuing enrichment of an innocent recipient is resolved through the personal liability of the trustee for the breach of their duty. Third, a claim for abstract wealth will only add an unnecessary burden for recipients. A suggested solution to the added risks created by the unjust enrichment analysis would be to provide an additional defence of change of position for the proprietary claim. But this would only serve to weaken the equitable regime by reducing the potency of the proprietary claim as a means of recovering misapplied property. Fourth, the recovery of testamentary property further illustrates that claims for the recovery of abstract wealth cannot operate alongside claims for the recovery of specific property.

The two measures, recovery of specific property and restitution of abstract wealth, reflect the fundamental distinction between cases where the claimant enjoys rights to recover identifiable property transferred in breach of a duty of preservation, and those where the claimant lacks any such rights. There is little to be gained by harmonising the equitable regime with the approach in unjust enrichment and much to be lost in the context of claims for the recovery of trust property. For the sake of coherence, and to protect the aims of the equitable regime, the unjust enrichment analysis must be excluded in claims for the receipt of trust property. 